\title{
APLIKASI VIRTUAL TOUR PURA TAMAN AYUN BERBASIS MULTIMEDIA INTERAKTIF
}

\author{
Ni Putu Sulistyadewi ${ }^{1}$, I Made Arya Krisdyantara ${ }^{2}$, Ni Made Rosita Juliandari ${ }^{3}$, Laras Sabrina \\ Saadia Soetrisno ${ }^{4}$, Riza Wulandari ${ }^{5}$ dan Edwar ${ }^{6}$
}

Institut Teknologi dan Bisnis (ITB) STIKOM Bali ${ }^{123456}$

\begin{abstract}
Taman Ayun Temple is a cultural-based tourist attraction located in Mengwi Village. Based on interviews conducted by NusaBali with the Taman Ayun Temple manager, it was said that during the COVID-19 Pandemic the number of visits to Taman Ayun Temple had decreased, which initially reached 1000 visitors per day to only 10 visits a day. Based on these problems, research was carried out to develop an Interactive Multimedia-based Virtual Tour Application, where this application is expected to help the existence of Taman Ayun Temple during the COVID-19 Pandemic while providing education to the public about the history of Taman Ayun Temple. In conducting this research, the author uses the MDLC (Multimedia Development Life Cycle) method, and to perform tests to determine functional errors that occur in the application, the author uses the black box testing method. Based on the test results conducted by the author, the application can run as expected, so the Interactive Multimedia-based Taman Ayun Temple Virtual Tour Application can be implemented to the community.
\end{abstract}

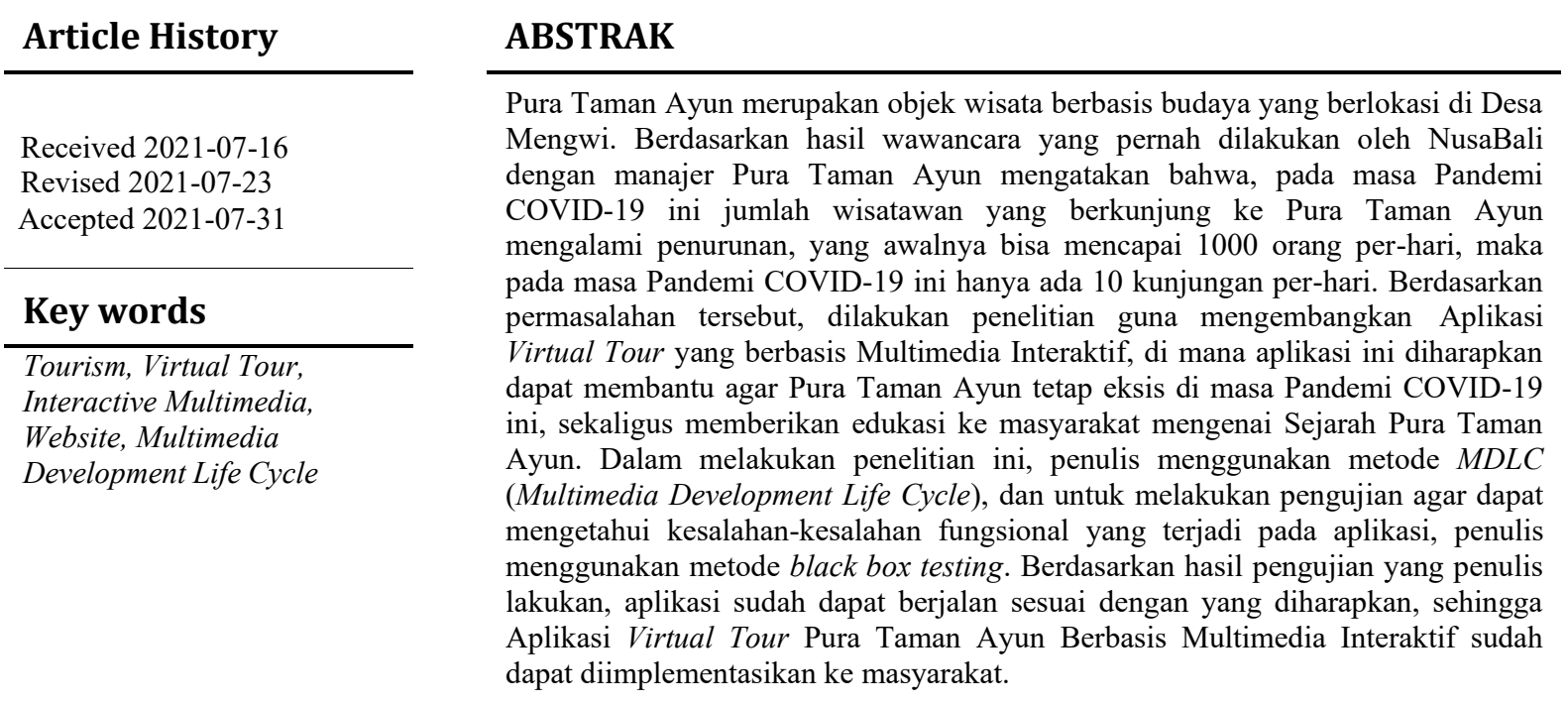

\section{PENDAHULUAN}

Perkembangan teknologi informasi menyebabkan penyebaran informasi semakin cepat dan luas, hingga ke seluruh penjuru dunia. Teknologi informasi merujuk pada seluruh bentuk teknologi yang digunakan untuk menciptakan, mengubah, dan menggunakan informasi dalam segala bentuknya [1]. Keberadaan teknologi informasi sangat mempengaruhi segala bidang, salah satunya adalah pada bidang pariwisata.

Di Indonesia, pariwisata merupakan bidang yang berkontribusi besar dalam perekonomian. Berdasarkan data yang diterbitkan oleh BPS (Badan Pusat Statistik) Provinsi Bali diketahui bahwa jumlah kedatangan wisatawan mancanegara dan domestik selama tahun 2015 sampai 2019 mengalami peningkatan, dan mengalami penurunan pada tahun 2020 akibat dari pandemi COVID19. BPS Provinsi Bali mencatat penurunan jumlah kedatangan wisatawan mancanegara ke Bali mencapai $-82,96 \%$, [2] dan untuk wisatawan domestik jumlah penurunannya mencapai $-56,41 \%$ [3]. Penurunan jumlah wisatawan ini memberikan dampak besar bagi pariwisata Bali, salah satunya pada objek wisata Pura Taman Ayun.

Biaya operasional objek wisata Pura Taman Ayun dalam sebulan dapat mencapai Rp 100 juta, sedangkan pendapatan yang dihasilkan sejauh ini tidak dapat menutupi biaya operasional, 
karena hanya ada 10 kunjungan per-hari. Untuk mengatasi permasalahan ini, penulis tertarik untuk membangun sebuah website yang dapat mendukung proses kegiatan pariwisata di Pura Taman Ayun. Dengan website ini, wisatawan dapat berkunjung dan memperoleh informasi mengenai Pura Taman Ayun secara virtual.

Berdasarkan hasil penelitian pada paper [4], yang berjudul "Aplikasi Virtual Tour Tempat Wisata Alam di Sulawesi Utara" teknologi virtual tour dibangun menggunakan metode Multimedia Development Life Cycle (MDLC). Penelitian sejenis juga dilakukan pada paper [5] yang berjudul "Aplikasi Virtual Tour Berbasis Web Sebagai Media Promosi Pariwisata", pada penelitian ini teknologi virtual tour menggunakan layanan geolocation dan berbasis web. Penelitian yang berjudul "Aplikasi Virtual Tour Berbasis Multimedia Interaktif Pada Objek Wisata Qubu Resort Pontianak" pada paper [6] juga menggunakan teknologi virtual tour dan berbasis multimedia interaktif. Namun, ketiga penelitian yang sudah ada ini hanya menggunakan teknologi virtual tour serta tidak ada penjelasan mengenai situasi di lokasi tersebut. Maka dari itu, dalam penelitian ini, virtual tour yang ada pada website yang penulis rancang akan dilengkapi dengan narasi suara seolah-olah pengguna sedang diajak berkeliling oleh seorang tour guide. Pengguna juga dapat berinteraksi secara interaktif dengan sistem untuk mendapatkan informasi-informasi mengenai Pura Taman Ayun.

\section{TINJAUAN PUSTAKA}

\section{Multimedia Interaktif}

Multimedia Interaktif merupakan multimedia yang memiliki tampilan yang berfungsi untuk menyampaikan informasi atau pesan serta memiliki interaksi dengan penggunanya [7]. Multimedia interaktif mampu memberikan timbal balik kepada penggunanya, di mana pengguna dapat berinteraksi dengan proyek multimedia sehingga pengguna dapat memperoleh informasi.

\section{Website}

Website yang dalam bahasa Indonesia berarti situs merupakan kumpulan halaman-halaman yang digunakan untuk menampilkan informasi baik berupa teks, gambar yang bergerak atau diam, animasi, suara maupun gabungan dari semuanya, di mana website ini memiliki 2 (dua) buah sifat yaitu statis dan dinamis, nantinya website ini akan membentuk satu rangkaian bangunan yang saling terkait dan dihubungkan dengan jaringan-jaringan halaman [8].

\section{Virtual Tour}

Virtual Tour merupakan teknologi yang menempatkan pengguna di dalam sebuah data virtual, di mana hal ini memungkinkan pengguna untuk meningkatkan kesadaran, daya lihat, tangkap dan analisisnya [9]. Virtual Tour ini dapat menunjukkan keadaan di suatu lokasi tertentu kepada pengguna, sehingga pengguna dapat memperoleh informasi tanpa harus datang langsung ke lokasi yang diinginkan.

\section{Pariwisata}

Pariwisata merupakan kegiatan perjalanan yang dilakukan oleh individu atau kelompok yang bertujuan untuk menghibur diri, menikmati fasilitas serta layanan dengan cara meninggalkan tempat tinggal mereka dan berpergian ke daerah wisata [10].

\section{METODE}

Metode penelitian yang digunakan dalam pembuatan Aplikasi Virtual Tour Pura Taman Ayun berbasis Multimedia Interaktif ini berorientasi pada Multimedia Development Life Cycle $(M D L C)$. 


\section{Konsep (Concept)}

Pada tahap konsep atau pengonsepan ini, penulis akan melakukan analisis menggunakan analisis $5 \mathrm{~W}+1 \mathrm{H}$. Di mana hasil dari analisis ini digunakan sebagai acuan dalam menyusun konsep Aplikasi Virtual Tour Pura Taman Ayun.

\section{Desain (Design)}

Pada tahap desain ini akan dibuat spesifikasi secara rinci mengenai menu-menu yang ada di dalam website Aplikasi Virtual Tour Pura Taman Ayun. Dalam pembuatan desain, dibutuhkan dukungan dari banyak perangkat keras dan perangkat lunak.

\section{Pengumpulan Data (Material Collecting)}

Pada tahap ini, akan dilakukan pengumpulan data atau bahan yang sesuai dengan kebutuhan untuk merancang Aplikasi Virtual Tour Pura Taman Ayun Berbasis Multimedia Interaktif. Adapun teknik pengumpulan data yang digunakan adalah studi literatur yang didapatkan dari artikel terkait Virtual Tour, Observasi, dan Wawancara kepada bapak I Made Suandi selaku Manajer Pura Taman Ayun.

\section{Perancangan Aplikasi (Assembly)}

Pada tahap perancangan aplikasi ini, semua bahan yang sudah didapatkan akan dikumpulkan untuk pembuatan aplikasi. Bahan-bahan ini mencangkup foto-foto serta video yang akan ditaruh pada Aplikasi Virtual Tour Pura Taman Ayun.

\section{Pengujian Aplikasi (Testing)}

Pada tahap ini akan dilakukan pengujian dengan cara menjalankan aplikasi virtual tour yang ada di dalam website yang telah dibuat untuk mengetahui dan melihat apakah ada kesalahan atau tidak.

\section{Distribusi (Distribution)}

Pada tahap distribusi ini, aplikasi yang dibangun akan didistribusikan menggunakan media online yang meliputi Website, Sosial Media dan YouTube. Di mana target atau pengguna utama dari aplikasi ini adalah masyarakat luas yang ingin mengenal Pura Taman Ayun tetapi tidak dapat berkunjung secara langsung.

\section{HASIL DAN PEMBAHASAN}

\section{Struktur Menu}

Struktur menu merupakan perancangan mengenai struktur dari menu-menu yang bisa diakses pada Aplikasi Virtual Tour Pura Taman Ayun. Jadi, Struktur menu ini akan menjadi acuan pada tahap pembuatan aplikasi. Berikut ini merupakan struktur menu pada Aplikasi Virtual Tour Pura Taman Ayun, yang dijelaskan pada Gambar 1.

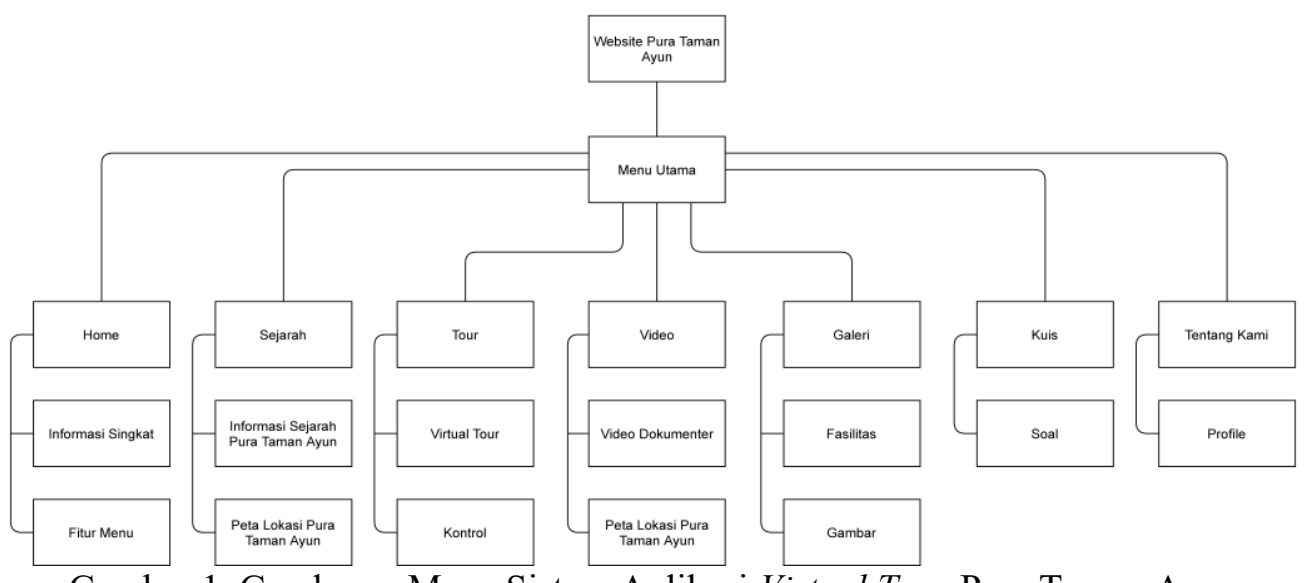

Gambar 1. Gambaran Menu Sistem Aplikasi Virtual Tour Pura Taman Ayun 


\section{Flowchart}

Flowchart atau bagan alir merupakan gambaran yang menampilkan hubungan antar proses serta instruksinya. Berikut ini merupakan flowchart yang akan menggambarkan proses alur kerja pada Aplikasi Virtual Tour Pura Taman Ayun secara umum.

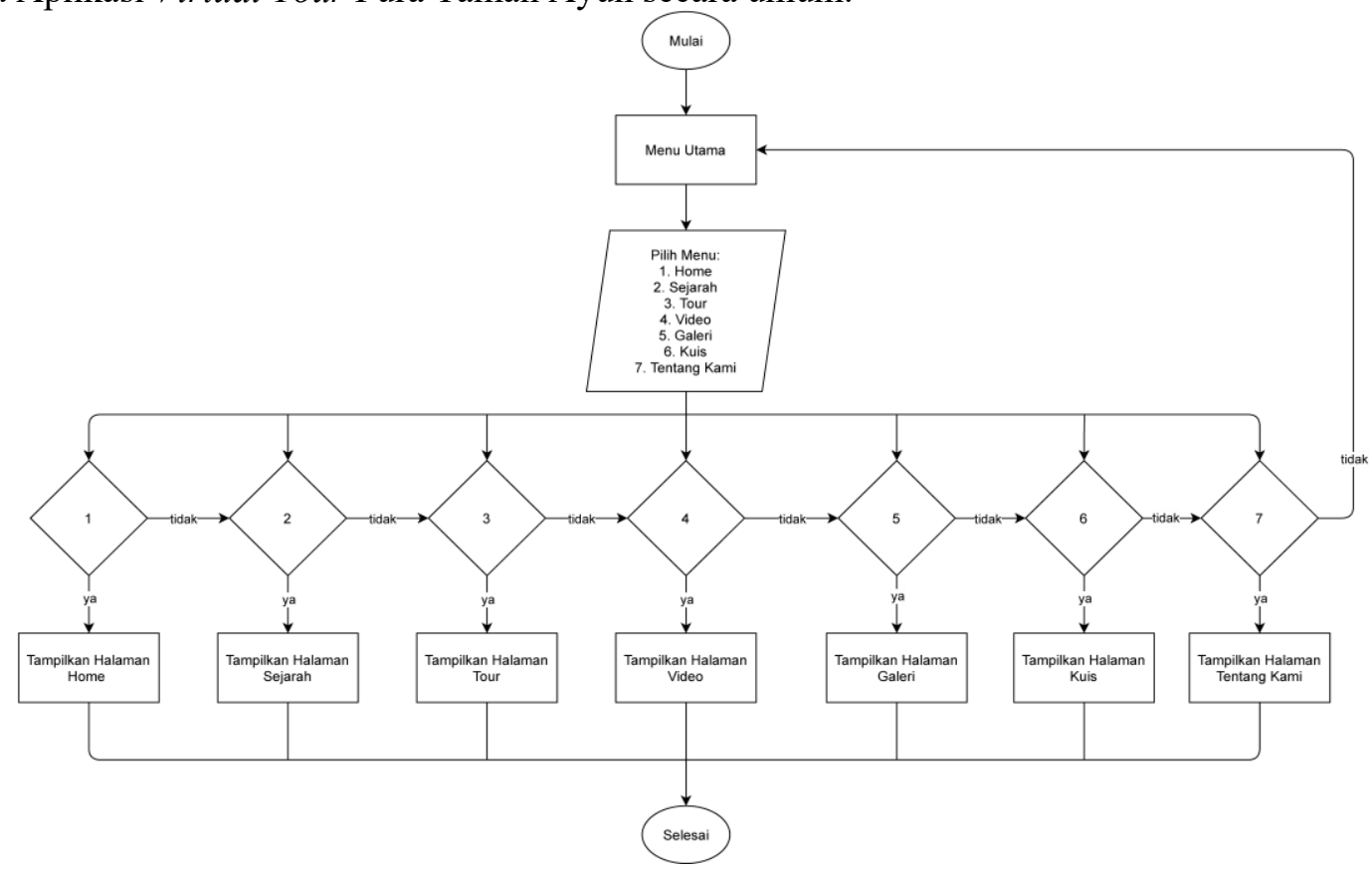

Gambar 2. Flowchart umum Aplikasi Virtual Tour Pura Taman Ayun

\section{Hasil Implementasi Sistem}

Implementasi sistem merupakan hasil dari gabungan seluruh bahan-bahan baik berupa objek maupun informasi sehingga dapat menjadi Aplikasi yang sesuai dengan perancangan yang telah dilakukan. Berikut ini merupakan Implementasi dari Aplikasi Virtual Tour Pura Taman Ayun Berbasis Multimedia Interaktif.

1. Halaman Menu Home

Menu Home merupakan halaman yang tampil paling awal saat pengunjung membuka halaman website.

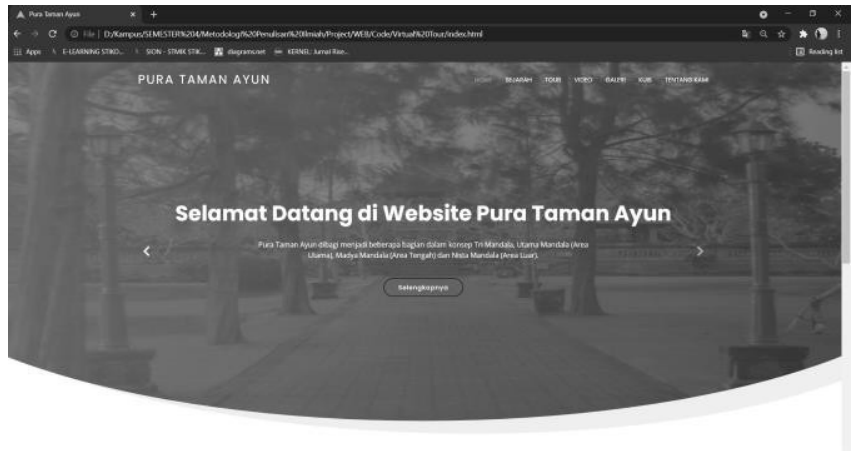

Gambar 3. Halaman Menu Home

2. Halaman Menu Sejarah

Menu Home merupakan halaman yang tampil ketika pengunjung ingin mengetahui informasi mengenai sejarah serta lokasi Pura Taman Ayun. 


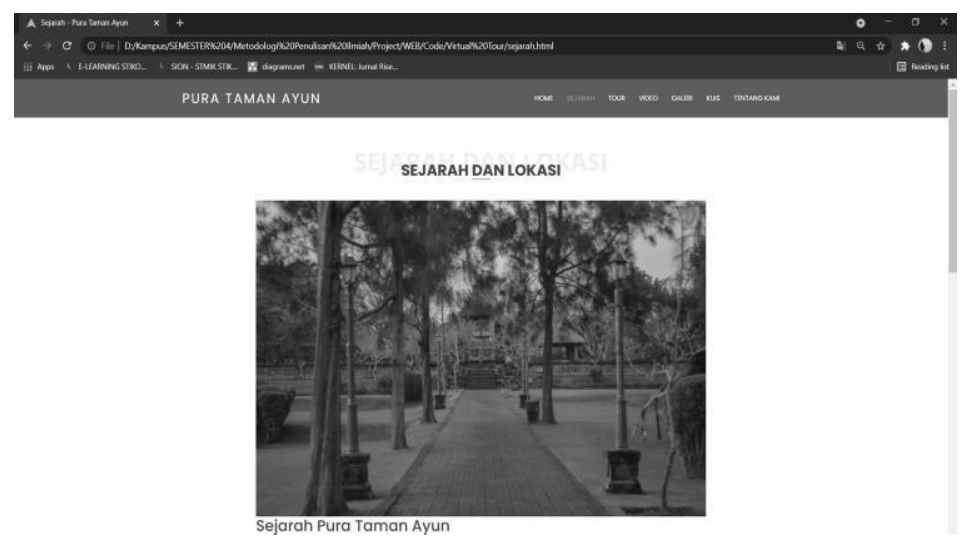

Gambar 4. Halaman Menu Sejarah

3. Halaman Menu Tour

Menu Tour merupakan halaman yang tampil ketika pengunjung ingin melakukan perjalanan berbasis budaya, melalui kacamata virtual di Pura Taman Ayun.

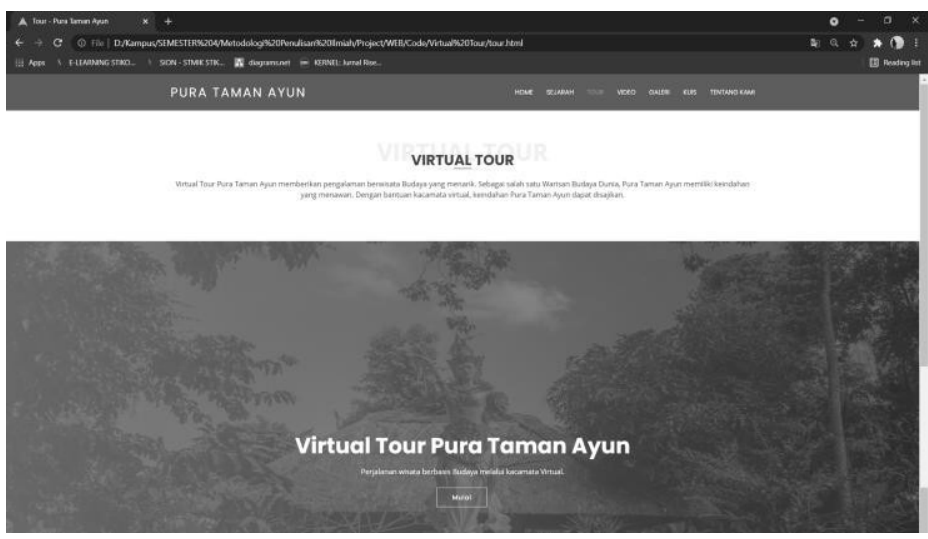

Gambar 5. Halaman Menu Tour

4. Halaman Virtual Tour

Halaman Virtual Tour merupakan halaman yang akan menampilkan virtual tour Pura Taman Ayun.

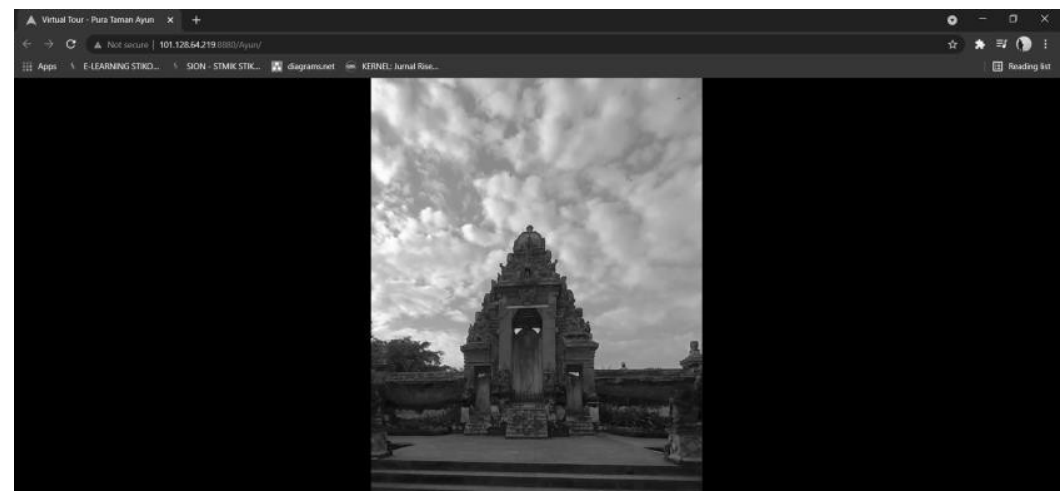

Gambar 6. Halaman Virtual Tour

5. Halaman Menu Video

Menu Video merupakan halaman yang tampil ketika pengunjung ingin menonton video dokumentasi Pura Taman Ayun. 


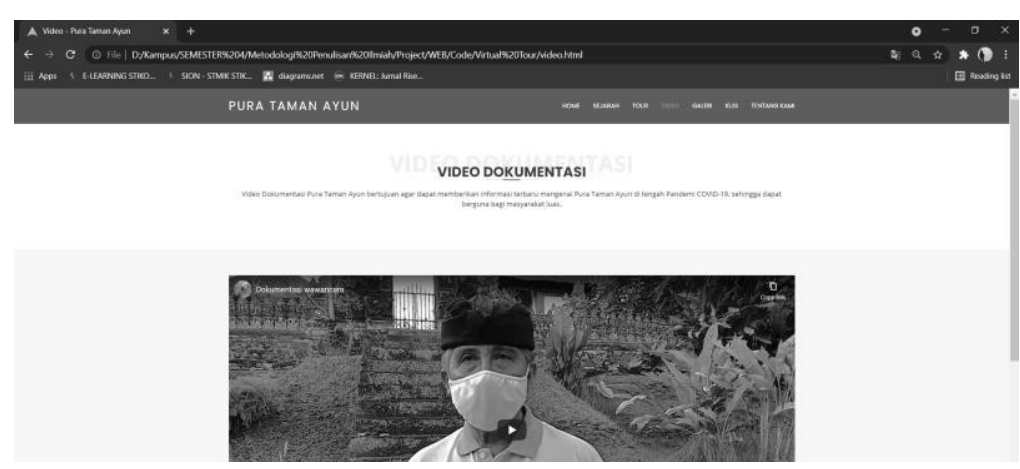

Gambar 7. Halaman Menu Video

6. Halaman Menu Galeri

Menu Galeri merupakan halaman yang tampil ketika pengunjung ingin melihat foto-foto lokasi Pura Taman Ayun.

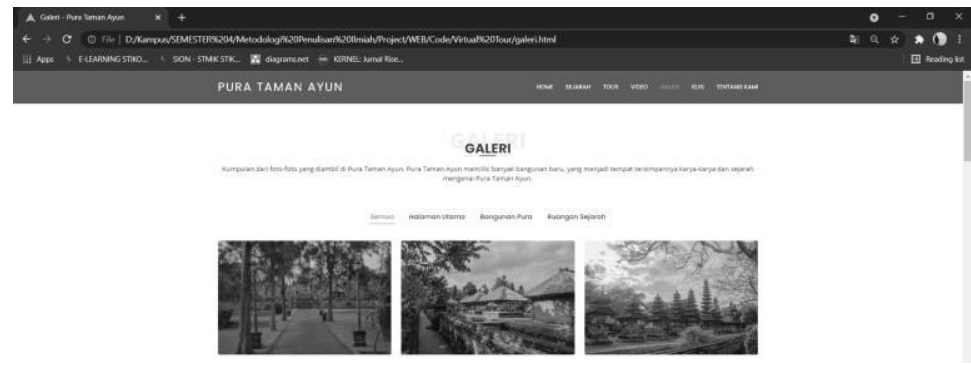

Gambar 8. Halaman Menu Galeri

7. Halaman Menu Kuis

Menu Kuis merupakan halaman yang tampil ketika pengunjung ingin menjawab soal seputar Pura Taman Ayun

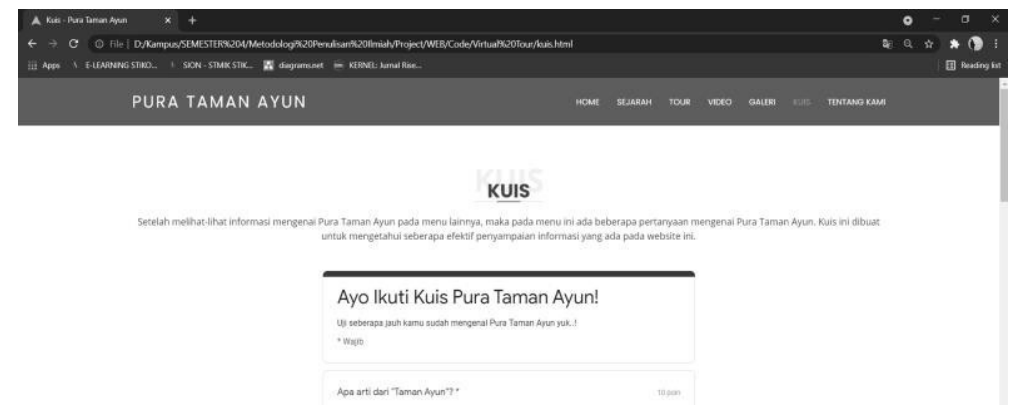

Gambar 9. Halaman Menu Kuis

8. Halaman Menu Tentang Kami

Menu Tentang Kami merupakan halaman yang tampil ketika pengunjung ingin profile dari penulis atau developer Aplikasi Virtual Tour Pura Taman Ayun Berbasis Multimedia Interaktif. 


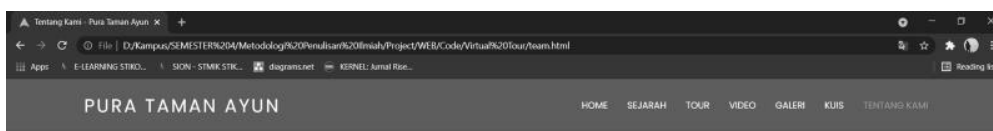

TENTANG KAMI
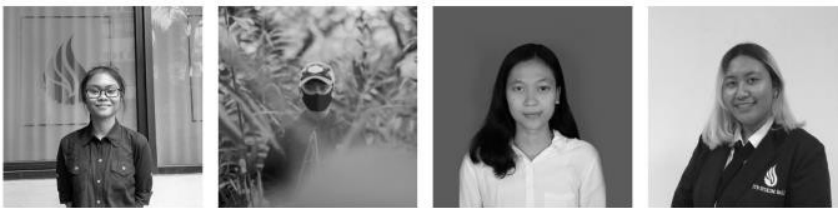

Gambar 10. Halaman Menu Tentang Kami

\section{Pengujian Sistem}

Pengujian sistem ini dilakukan untuk mengetahui apakah ada kesalahan pada fungsi-fungsi yang ada di Aplikasi Virtual Tour Pura Taman Ayun Berbasis Multimedia Interaktif ini, sehingga kesalahan tersebut dapat segera diperbaiki agar sistem dapat berjalan sesuai dengan yang diharapkan.

Tabel 1. Pengujian Sistem

\begin{tabular}{|c|c|c|c|c|}
\hline No & Kelas Uji & Hasil Yang Diharapkan & Hasil Pengujian & Keterangan \\
\hline 1 & Button Home & $\begin{array}{l}\text { Aplikasi } r \text { akan } \\
\text { menampilkan halaman } \\
\text { home. }\end{array}$ & $\begin{array}{l}\text { Aplikasi berhasil } \\
\text { menampilkan } \\
\text { halaman home. }\end{array}$ & Sesuai \\
\hline 2 & Button Sejarah & $\begin{array}{lr}\text { Aplikasi } & \text { akan } \\
\text { menampilkan } & \text { halaman } \\
\text { sejarah. }\end{array}$ & $\begin{array}{l}\text { Aplikasi berhasil } \\
\text { menampilkan } \\
\text { halaman sejarah. }\end{array}$ & Sesuai \\
\hline 3 & Button Tour & $\begin{array}{lr}\text { Aplikasi } & \text { akan } \\
\text { menampilkan } & \text { halaman } \\
\text { tour. }\end{array}$ & $\begin{array}{l}\text { Aplikasi berhasil } \\
\text { menampilkan } \\
\text { halaman tour. }\end{array}$ & Sesuai \\
\hline 4 & $\begin{array}{l}\text { Button Mulai } \\
\text { Tour }\end{array}$ & $\begin{array}{lr}\text { Aplikasi } & \text { akan } \\
\text { menampilkan } & \text { halaman } \\
\text { virtual tour. } & \end{array}$ & $\begin{array}{l}\text { Aplikasi berhasil } \\
\text { menampilkan } \\
\text { halaman virtual } \\
\text { tour. }\end{array}$ & Sesuai \\
\hline 5 & Button Video & $\begin{array}{lr}\text { Aplikasi } & \text { akan } \\
\text { menampilkan } & \text { halaman } \\
\text { video. }\end{array}$ & $\begin{array}{l}\text { Aplikasi berhasil } \\
\text { menampilkan } \\
\text { halaman video. }\end{array}$ & Sesuai \\
\hline 6 & Button Galeri & $\begin{array}{lr}\text { Aplikasi } & \text { akan } \\
\text { menampilkan } & \text { halaman } \\
\text { galeri. } & \end{array}$ & $\begin{array}{l}\text { Aplikasi berhasil } \\
\text { menampilkan } \\
\text { halaman galeri. }\end{array}$ & Sesuai \\
\hline 7 & Button Kuis & $\begin{array}{l}\text { Aplikasi } r \text { akan } \\
\text { menampilkan halaman } \\
\text { kuis. }\end{array}$ & $\begin{array}{l}\text { Aplikasi berhasil } \\
\text { menampilkan } \\
\text { halaman kuis. }\end{array}$ & Sesuai \\
\hline 8 & $\begin{array}{ll}\text { Button } & \text { Tentang } \\
\text { Kami } & \end{array}$ & $\begin{array}{lr}\text { Aplikasi } & \text { akan } \\
\text { menampilkan } & \text { halaman } \\
\text { tentang kami. } & \end{array}$ & $\begin{array}{l}\text { Aplikasi berhasil } \\
\text { menampilkan } \\
\text { halaman tentang } \\
\text { kami. }\end{array}$ & Sesuai \\
\hline
\end{tabular}

\section{KESIMPULAN}

Berdasarkan hasil dari penelitian yang telah dilakukan, maka diperoleh kesimpulan diantaranya:

1. Perancangan sistem pada Aplikasi Virtual Tour Pura Taman Ayun Berbasis Multimedia Interaktif ini menggunakan Struktur Menu, serta Flowchart untuk membuat aplikasinya. 
2. Pengujian yang dilakukan dengan metode black box testing menunjukkan bahwa aplikasi telah berjalan sesuai dengan yang diharapkan.

3. Telah dihasilkan sebuah Aplikasi Virtual Tour Pura Taman Ayun Berbasis Multimedia Interaktif.

\section{DAFTAR PUSTAKA}

[1] Suyanto, Pengantar Teknologi Informsi untuk Bisnis, Edisi Pert. Yogyakarta: Andi, 2005.

[2] B. P. Statistik, "Number of Foreign Visitor to Indonesia and Bali, 1969-2020." [Daring]. Tersedia pada: https://bali.bps.go.id/statictable/2018/02/09/28/banyaknya-wisatawanmancanegara-ke-bali-dan-indonesia-1969-2020.html.

[3] B. P. Statistik, "Number of Domestic Visitor to Bali by Month, 2004-2020." [Daring]. Tersedia pada: https://bali.bps.go.id/statictable/2018/02/09/29/banyaknya-wisatawandomestik-bulanan-ke-bali-2004-2020.html.

[4] H. W. Wulur, S. Sentinuwo, dan B. Sugiarso, "Aplikasi Virtual tour Tempat Wisata Alam di Sulawesi Utara," J. Tek. Inform., vol. 6, no. 1, hal. 1-6, 2015, doi: 10.35793/jti.6.1.2015.9953.

[5] P. D. Dwi, "Aplikasi Virtual Tour Berbasis Web Sebagai Media Promosi Parawisata," no. May, 2011, [Daring]. Tersedia pada: http://elektro.um.ac.id/ceie/2011/assets/paper/National/Informatics/A2-10 - DIDIK_DWI_P - VIRTUAL TOUR BERBASIS WEB.pdf.

[6] N. Safriadi, H. Sastypratiwi, dan N. Tamara, "Aplikasi Virtual Tour Berbasis Multimedia Interaktif Pada Objek Wisata Qubu Resort Pontianak," Semin. Nas. Teknol. Inf. Dan Komun. X, vol. 3, no. 1, hal. 411-416, 2018.

[7] Munir, Multimedia Konsep \& Aplikasi Dalam Pendidikan, vol. 58, no. 12. Bandung: Alfabeta, 2020.

[8] H. Bekti, Mahir Membuat Website dengan Adobe Dreamweaver CS6, CSS, dan JQuery. Yogyakarta: Andi, 2015.

[9] A. Osman, N. Wahab, dan M. Ismail, "Development and Evaluation of an Interactive 360 Virtual Tour for Tourist Destinations," J. Inf. Technol. Impact, vol. 9, no. 3, hal. 173-182, 2009, [Daring]. Tersedia pada: http://scholar.google.com/scholar?hl=en\&btnG=Search\&q=intitle:Development + and + Evalu ation + of + an + Interactive $+360+{ }^{\circ}+$ Virtual + Tour + for + Tourist + Destinations $\# 0$.

[10] P. D. I. G. Pitana dan I. P. G. Gayatri, Sosiologi Pariwisata, Edisi Pert. Yogyakarta: Andi, 2005. 